\title{
ВЛАДИМИР НИКОЛАЕВИЧ ДАВ - ИССЛЕДОВАТЕЛЬ И ПОПУЛЯРИЗАТОР ЦВЕТНОГО КАМНЯ КОЛЬСКОГО КРАЯ
}

\section{Лащук В.В.}

Институт химии и технологии редких элементов и минерального сырья им. И.В. Тананаева КНЦ РАH, Anamumbl,lashchuk@chemy.kolasc.net.ru

Разбирая старые бумаги, я нашел рукопись служебной записки старшего инженера Владимира Николаевича Дава, руководителя группы цветного камня Лаборатории природного камня Мончегорской группы лабораторий (МГЛ) ИХТРЭМС Кольского филиала (КФ) АН СССР (рис. 1).
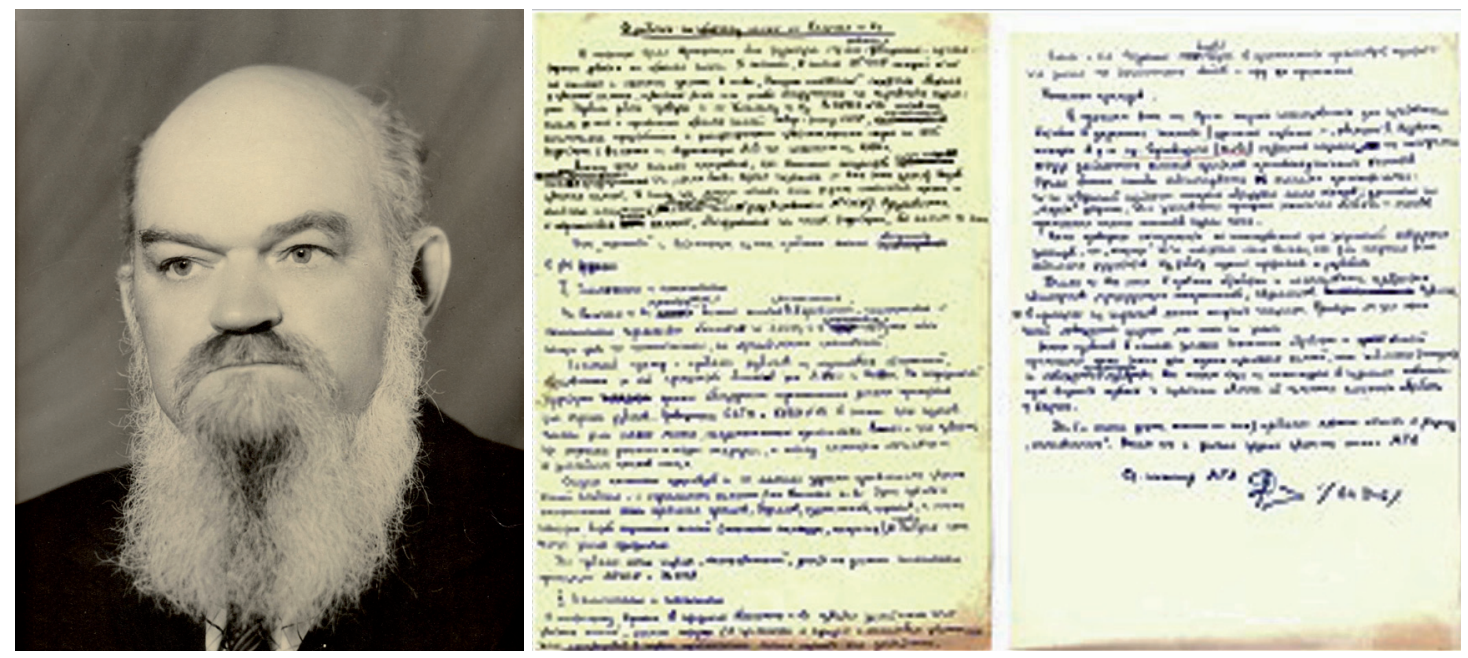

Рис. 1. Слева: фото Дава В.Н., руководителя группы цветного камня МГЛ [17],

Справа: рукопись его служебной записки «О работах по цветному камню Кольского полуострова».

Эта рукопись послужила толчком к воспоминанию о совместной работе групп облицовочного и цветного камня (1971-1975 гг.). Её, датируемую 1969 г., мне раньше любезно предоставила Гуревич Б.И., к.т.н., ведущий научный сотрудник Лаборатории минерального сырья и силикатного синтеза ОТСМ ИХТРЭМС, заслуженный строитель Российской Федерации, любитель и знаток кольских самоцветов (рис. 2).

Гуревич Б.И. прошла весь исторический путь от Лаборатории строительных материалов 1953-1961 гг., созданой Теннером Д.Д. при Геологическом институте (ГИ) КФ АН СССР на промышленной площадке ГМК «Североникель» в городе Мончегорске до ОТСМ ИХТРЭМС КНЦ РАН в городе Апатиты (с 1975 года по настоящее время). Здесь цветнокаменная тематика практически отсутствует.

Немного об истории изучения цветного камня Мурманской области.

В книге академика А.Е. Ферсмана «Полезные ископаемые Кольского полуострова» приводятся результаты исследований минерального сырья за все предвоенное время [18]. В перечне по-
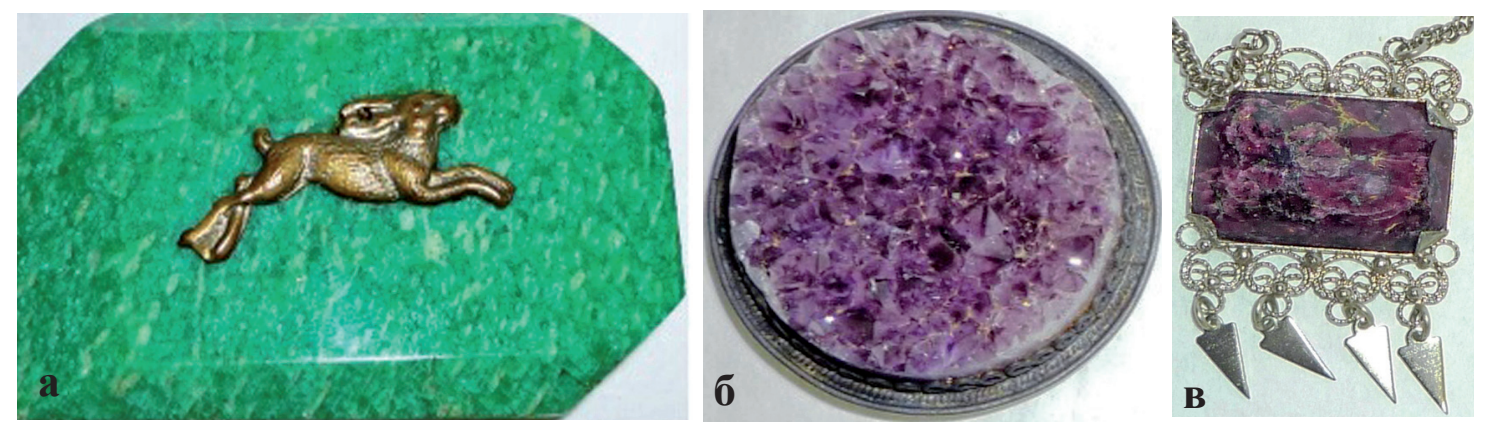

Рис. 2. Ювелирные изделия из кольских самоцветов коллекции Гуревич Б.И.: $\mathrm{a}$ - амазонит кейвский, б - аметист терский, в - эвдиалит хибинский (фото Семушина В.В.). 
лезных ископаемых есть упоминание о цветном камне. «Частично, сюда следует отнести обработку местных минералов и пород для мелких поделок в Кировске; небольшая кустарная мастерская, одно время прекратившая свою работу, ныне вновь организуется (1940 г.). Наиболее интересными являются хибинит, плотный зеленый тингуаит, красная кремнистая брекчия (ст. Хабозера), сфеновая порода (титанит)_Юкспорра, эвдиалит, плотный_доломит (ст. Титан)» [18, С. 17]. То есть отмечены шесть видов цветного камня (подчеркнуты), из которых большая часть - это попутно добываемое минеральное сырьё.

В послевоенное время восстанавливался Мурманск, осваивались горно-рудные районы, создавались новые социалистические города, например, Оленегорск, Ковдор, Заполярный, Полярные Зори. При активном участии академика Сидоренко А.В. в 60-е годы велось строительство Нового города, который в 1966 г. получил название - Апатиты [17].

Природнокаменная тематика и соответствующая ей Лаборатории природного камня были созданы в 1969 г. одновременно в ИХТРЭМС Кольского филиала (заведующий Туркин А.Ф.) и в Институте Геологии Карельского филиала АН СССР (заведующий к.г-м.н. Рылеев А.В.). В этом же году, по приглашению Теннера Д.Д., поступил на работу в МГЛ старший инженер-геолог ПО «Союзкварцсамоцветы» Министерства Геологии (МГ) СССР Дав В.Н. Научным обоснованием для исследований природнокаменного сырья послужили обзоры по облицовочному и цветному камню ранее проведенных работ в ГИ Кольского филиала АН СССР (фонды КФ АН СССР: Горюнов В.М., 1959, 1969; Пушкин Г.Ю., 1969) и публикации Теннора Д.Д. [16]. Организационной и финансовой основой для расширения исследований минерального сырья стройиндустрии Мурманской области стало Постановление Совета Министров СССР № 94 от 9 февраля 1968 г. «О мерах по дальнейшему развитию городов Архангельска и Мурманска» [11].

Летом 1971 г., я, молодой специалист геологического факультета Львовского университета, приехал в Мончегорск. Едва переводя дух и устроившись в рабочем общежитии ГМК «Североникель» «Уют», отправился на «козле» вместе с младшим научным сотрудником Алексеевым Г.В. в первое поле - в Печенгский промышленный район. Там, я впервые познакомился с огромными рудными каръерами, с первым разведанным на Кольском полуострове в 1970 году месторождением облицовочного камня - доломитовыми мраморами Пирттиярви [16]. В Центральном (Ждановском) карьере осуществлялись масштабные работы по вскрыше рудной зоны. Здесь, мы под руководством старшего научного сотрудника ГИ КФ АН СССР Макарова В.Н., в вертикальных уступах осваивали методику исследования трещиноватости горных пород Пильгуярвинского массива. Это наиболее крупное магматическое тело базит-гипербазитов Печенгского рудного поля. Здесь иногда встречались прожилки зеленого серпофита и белого кальцита, реже - выделения сиреневого аксинита. В опытно-промышленном разведочном мраморном карьере Пирттиярви прекрасное впечатление произвели белые с розовыми оттенками мраморы и два слоя коричневых кварцитопесчаников. В нижней части линзы, на контакте шаровой лавы с доломитовыми мраморами наблюдались слои зеленого хлоритизированного метамандельштейна. Он содержит равномерно рассеянные миндалины, заполненные белым кальцитом, розовым и красным доломитом. Здесь же, в одном из линзовидных тел мраморов, которые раньше обнаружил Горюнов В.М., были отобраны образцы окварцованных и гематизированных разновидностей. Они обладают насыщенной красной до шоколадного цвета окраской. Дав В.Н., этому сорту мрамора, присвоил названия «кольская, печегская яшма». Там же, вблизи вновь построенного города Заполярный, я впервые познакомился с последними бараками рудничного поселка Горный и холодным заполярным летом.

А в это же время, в Ёно-Ковдорском районе, Дав В.Н. ездил со своим экспедиционным отрядом на машине типа «газон-53» по проявлениям цветного камня. Но не долго: при возвращении домой эта техника поломалась на полпути, так называемой, дороги «Ковдор-Пиренга (Рыбзавод)». В последующие десятилетия экспедиционные отряды МГЛ пользовались трехосным грузовиком ЗИЛ-157, внешне очень похожим на своего родственника «Студебеккера». В народе его именовали ласковым словом «Захар», учитывая его достаточно суровый характер. Это проявлялось обычно в осенний период, когда в полевых условиях, после первых заморозков, эта «железяка» достаточно долго не желала заводиться. 
После первого полевого сезона, осенью 1971 г. Лаборатория природного камня, активно, как и вся МГЛ, переезжала с промышленной площадки МК «Североникель» в отремонтированные здания закрытого в 1968 г. рудоуправления «Ниттис-Кумужье». Обустройство на новом месте продолжалось несколько лет. Появидись молодые специалисты, лаборатория оснащалась новым научным, технологическим оборудованием. Шлифовальная мастерская получила современные станки, а лаборатория природного камня приобрела коллекцию цветного камня, которую Академия Наук закупила на выставке «Стройматериалы-1970».

В служебной записке «О работах по цветному камню Кольского полуострова» Дав В.Н. уделил особое внимание технологической оценке горных пород и минералов как поделочных и ограночных камней. Он отмечает, что промышленными видами цветного камня являются терские аметистовые щетки и кейвские амазониты. Проявления ювелирного сырья весьма редкие, например, эпизодические россыпи рубинов из ледниковых отложений рек Лотты и Ноты. Проявления поделочного камня, приуроченные к околорудной зоне горно-добывающих предприятий, также не надежный источник цветнокаменного сырья. Поэтому для детальных исследований Дав В.Н. предложил исследовать новые проявления цветного камня. Это такие, как «печенгская яшма» (коммерческое название гемматизированных доломитов по Даву В.Н.), кейвские кианиты хребта Серповидного, ковдорские диопсиды, «серебристые авантюрины» - мусковитизированные кварциты, ёнские ирризирующие микроклины и ловозерские трахитоидные луявриты. Как видно, количество цветных камней существенно увеличилось вследствие расширения региональных исследований Кольского райГРУ, преобразованного в Мурманскую ГРЭ (МГРЭ) Северо-Западного Территориального Геологического Управления (СЗГТУ) МГ СССР.

В следующем 1972 г. молодые специалисты группы облицовочного камня под руководством Дава В.Н. активно знакомились с цветно каменной тематикой, практиковались и привлекались в качестве экскурсоводов музея цветного камня, созданного В.Н. Давом. Экспозиция содержала его личную коллекцию цветного камня СССР, пополнялась кольским камнем, а также включала минералогическую коллекцию доктора геолого-минералогических наук профессора Горного института Чупилина Ивана Ильича. Эта коллекция приобретена на средства жителей города. Музей являлся составной частью лаборатории природного камня и вместе с сотрудниками располагался в отдельном домике, бывшем здании горноспасательного отряда. Популяризация научных знаний о цветном камне Кольского края осуществлялась Давом В.Н. в Клубе любителей камня, заседания которого проводились в выходные дни, в недавно построенном Дворце металлургов на центральной площади Мончегорска (рис. 3).

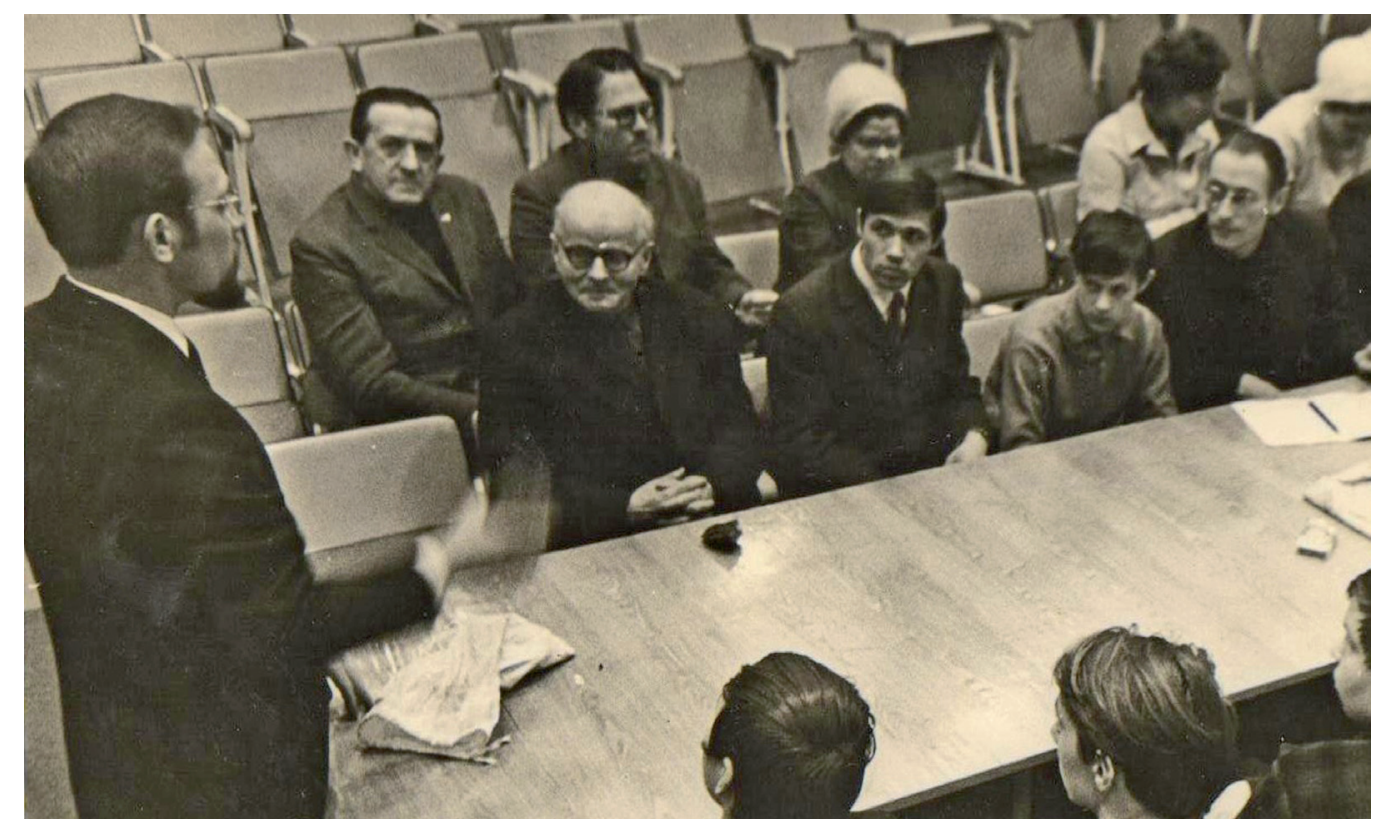

Рис. 3. Доклад Бибикова Б.И. о калиниградском янтаре на заседании Мончегорского клуба любителей камня (фото Мурманского телевидения, 1974 г.). 
Технологические исследования облицовочного и цветного камня проводились в шлифовальнополировальной мастерской, которая располагалась в бывшем бытовом корпусе рудоуправления. Работы по обработке каменного сырья осуществляли квалифицированные мастера: камнерез Рыбин В.К. и огранщица Барабохина Н.И., дипломированные выпускники Ленинградского СПТУ. Нужно отметить, что Рыбин В.К. в течении трудовой деятельности проработал в трех институтах КНЦ РАН: Геологическом, Горном, Институте химии, а также и в трех комбинатах: «Апатит», «Североникель» и «Апатитстрой» (ПО «Апатитстройиндустрия»). Он воспитал учеников. Среди них можно, например, выделить шлифовщика ОТСМ Степанова В.В., который также, как и учитель, является многократным лауреатом ежегодной Апатитской выставки-ярмарки «Каменный цветок», отметившей в этом году 25-ти летний юбилей.

Мне особенно запомнился полевой сезон 1973 г., который под руководством начальника экспедиционного отряда Дава В.Н. был посвящен изучению проявлений цветного камня в карьерах апатит-нефелиновых месторождений Хибин, в Ловозерских тундрах и на Мурманском побережье, в районе Серебрянской ГЭС-1.

В Хибинах, на плато Расвумчорр, мы обследовали верхние уступы, зарождающегося карьера рудника «Центральный». Здесь, как и на плато Юкспорр, наблюдались широкие, протяженные полосы коричневого сфенита (сфеновая, то есть по современной терминологии титанитовая порода), небольшие пегматитовые жилы, содержащие сиреневый эвдиалит.

В Ловозерских тундрах был осуществлен ознакомительный пешеходный переход по маршруту горняцкий поселок Ильма - Моткегуба. Лето было удивительно жарким. На плоских вершинах было $+30^{\circ} \mathrm{C}$, обсохли ручьи и воду можно было достать только в редко встречающихся карровых озерках. В нижней части горы Вавнбед, на контакте Ловозерского массива с гнейсовой толщей, в небольшом разведочном шурфе насобирали мешочек коричневых кристаллов циркона. Размер кристаллов 5-15 мм в поперечнике, форма - тетрагональная дипирамида. Однако эти кристаллы обычно трещиноватые, непрозрачные, поэтому представляют только минералогический интерес. Что касается коллекционных камней, то здесь наблюдается большое разнообразие. Например, в районе горы Нинчурт, в старых шурфах находили жилы гакманита, участки луявритов, содержащих скопления эгириновых звезд. Впечатлили мощные слои эвдиалитовых луявритов, в которых содержание эвдиалита иногда превышает половину объема горной породы. В скалистых котловинах чарующе выглядели озера с названиями Сейдъявр, Райявр. Внизу, на извилистых булыжных тропах нас атаковали тучи комаров и мошки.

Из села Ловозеро наш экспедиционный отряд на саамской лодке, оснащенной стационарным мотором, направился на север в 120-километровое плавание до плотины недавно построенной Серебрянской ГЭС-1. Погода была тихая. Плыли днем и ночью. На водных просторах я впервые прочувствовал на себе очарование летней заполярной ночи. Зрелище фантастическое, когда диск солнца делает круг над водным горизонтом, а облака полыхают оранжевыми, малиновыми и сиреневыми цветами. Была одна короткая остановка. Наш проводник, Григорий Иванович Кожин рассказал, что здесь на глубине около ста метров находится затопленное его родное саамское село Гаврилово. Утром причалили к крутой каменной насыпи плотины. Недалеко располагался наш полевой лагерь, где нас встречал Дав В.Н. Сюда примыкала территория бывшего лагерного поселка «Серебрянский», получившего свое название от речки Серебрянка. Как памятник стояла высокая караульная вышка, с которой хорошо просматривается недалеко расположенный карьер скальных пород. Обследование этой выработки показало, что горные породы представлены серыми биотитовыми гранодиоритами, среди которых наблюдаются светлые калишпатизированные разновидности с голубоватым кварцем.

В феврале 1972 г. произошло знаменательное событие - был запущен распиловочный станок на первом камнеобрабатывающем предприятии Мурманской области - участке обработки природного камня (УОПК) МК «Североникель». Участок организован по рекомендации МГЛ ИХТРЭМС КФ АН СССР (Теннер Д.Д.). По инициативе Владимира Николаевича Дава, в связи с рождением «первенца камнеобработки» из обрезков пироксенита первого блока облицовочного камня в шлифовальной мастерской МГЛ были изготовлены маленькие сувениры. На полированной поверхности изделий была выгравирована дата: «01.02.1972». Сырьем для УОПК послужили попутно добываемые блоки-негабариты вскрышных пород Пильгуярвинского медно-никелевого месторождения, 
которые разрабатывает ГМК «Печенганикель». Мончегорский УОПК производил товары народного потребления, включая памятники, строительно-архитектурные изделия и облицовочные плиты. А в следущем году, при этом участке была организована сувенирная мастерская. Под руководством Дава В.Н. был разработан проект обеспечения мастерской цветнокаменным сырьем, Рыбиным В.К. были созданы эскизы сувениров и технологические схемы производства этой продукции.

Мончегорский период ОТСМ у меня ассоциируется с Давом В.Н. Для него это было плодотворное время, как в музейной деятельности, так и в опубликовании результатов исследований цветного камня Кольского полуострова. После отъезда сотрудников ОТСМ в Апатиты Владимир Николаевич с 1976 г. работал в Центрально-Кольской поисково-съемочной экспедиции (ЦКПСЭ), которая была создана на базе Имандровской партии Мурманской ГРЭ. Также он заведовал Музеем цветного камня, который до 2007 г. располагался на Ленинградской набережной и затем переехал в центр города на проспект Металлургов (Жданова). В 2000 г. на 30-летие музею присвоено имя его создателя [3]. Основу экспозиции составила коллекция МГЛ, которая безвозмездно была передана КФ АН СССР городу Мончегорску. В этот же период Медвежегорская партия ПО «Союзкварцсамоцветы» МГ СССР осуществляла разведочные и поисковые работы на цветной камень. А позже Кольская партия этой экспедиции занималась исследованием и отбором минералогических коллекций для вузов и музеев. В частности, были разведаны месторождения амазонита на горе «Парусная», аметистовых щеток «Мыс Корабль». Эти виды цветного камня признаны уникальными [1, $4,5,15,19]$. Результаты своих исследований Дав В.Н., в научно-популярной форме представил частично в статье журнала «Химия и жизнь», 1979, № 2 и полно в книгах «Аметист лихие думы отгоняет», Мурманск, 1981 и «Камни радости», Мурманск, 1988 [6-8] (рис. 4).

Последняя монография опубликована уже после кончины автора, при содействии минералогов ГИ КНЦ РАН (Волошин А.В., Барабанов А.В.), геологов Имандровской ГРП (Турылев Н.Б.), журналистов Мурманского отделения Союза журналистов СССР (Попова С.А.) [8]. Книга включает две части. Первая часть посвящена описанию цветно каменного сырья преимущественно доступных промышленно развитых районов Кольского региона. Здесь затрагиваются также вопросы технологии обработки цветного камня и охраны геологических объектов природы. В предисловии к книге заслуженный деятель культуры РСФСР, заведующая редакцией Ленинградского телевидения Познякова Г. приводит воспоминания о деятельности Дава В.Н. по популяризации знаний на сцене КВН Горного института и в телевизионных передачах. Она отмечает, что Владимир Николаевич «прекрасно смотрелся», выступал замечательно, «в лучших традициях академика Ферсмана». Вторая часть представлена главой «Аметист лихие думы отгоняет», дублирующая первое издание 1981 г. Научный редактор этой книги, профессор кафедры минералогии Ленинградского госуниверситета Андрей Глебович Булах, в предисловии отметил, что это «одна из редких книг, которая предназначена для широкого круга читателей».
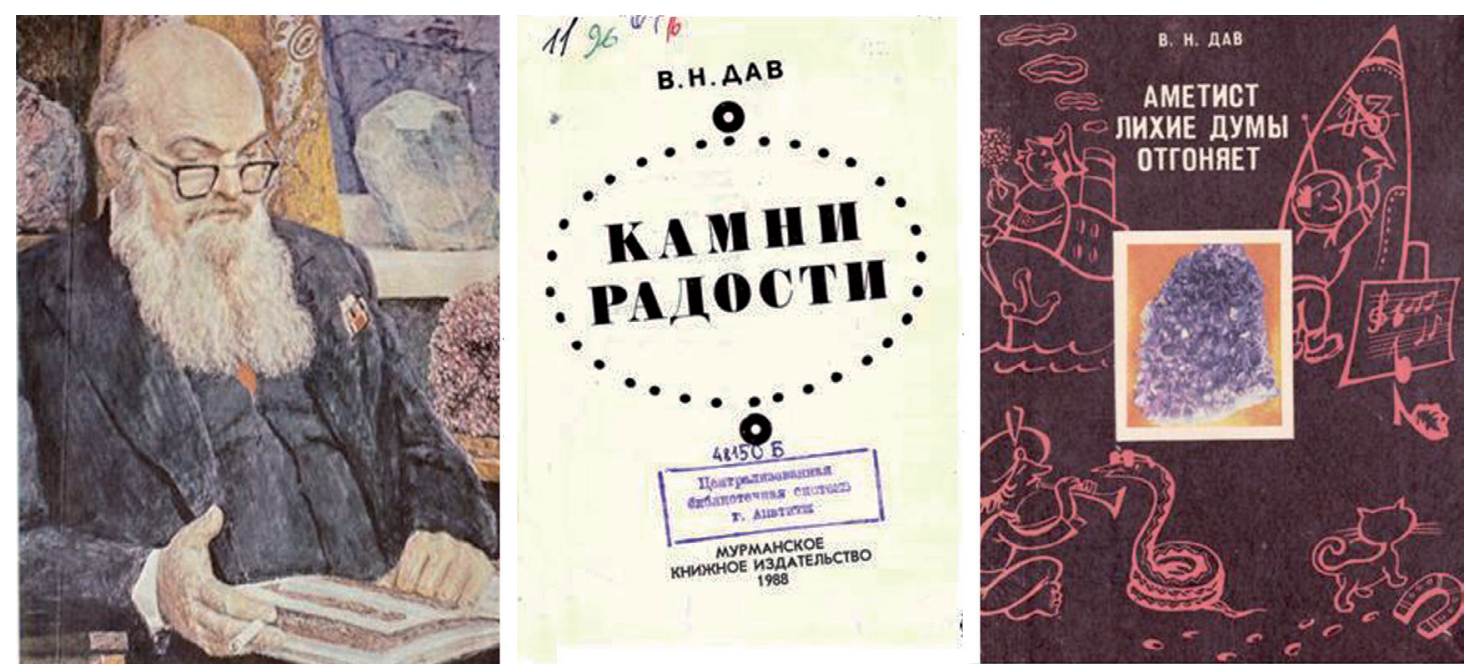

Рис. 4. Книги Дава В.Н., посвященные цветному камню Кольского края. 
В 1979 г. ОТСМ практически полностью перебазировался в академгородок Апатитов. Небольшая часть сотрудников осталась в Мончегорске и перешла на работу в Центральную заводскую лабораторию (ЦЗЛ) МК «Североникель», а другая часть на камнеобрабатывающие предприятия - УОПК, МКУ ПО «Карелстройматериалы», позже переданное в ПО «Мурманскстройматериалы». Дав В.Н. со своей цветнокаменной тематикой был радушно принят в ЦКПСЭ. Там, он курировал и консультировал поисково-оценочные работы, как на новых, так и на известных проявлениях цветного камня.

Автор благодарен за дополнения и замечания от профессоров Волошина А.В. и Войтеховского Ю.Л., руководителя Отдела инновации ГИ Жирова Д.В. и к.т.н. Гуревич Б.И. ИХТРЭМС, которые были получены автором в процессе написания этой публикации.

Таким образом, Владимир Николаевич Дав оказал существенное влияние на развитие интереса к цветному камню народных масс Кольского края. В настоящее время, в новых условиях хозяйственной деятельности индустрия самоцветов развивается на осколках советских камнеобрабатывающих предприятий. Широкое развитие получили художественные салоны, специализированные музеи и ежегодные ярмарки-выставки самоцветов от Екатеринбурга, Санкт-Петербурга до Апатитов.

Популяризацию научных знаний о самоцветах Кольского края продолжают музеи Мурманской области: Областной краеведческий музей в Мурманске, Геологический музей КНЦ РАН в Апатитах, Горный музей АО «Апатит» в Кировске и другие краеведческие музеи в своих экспозициях и на своих конференциях. В современных условиях, благодаря цифровой технологии, существенно повысилось качество фотографий цветного камня, ювелирных изделий, минералов. Научные и научнопопулярные издания используют эти возможности [1-4, 6, 11-14]. Например, когда бывший школьник, член мончегорского клуба любителей камня на свои средства в Санкт-Петербурге в 2017 г. переиздал книгу Дава В.Н., «Камни радости» и тираж подарил музею цветного камня [10]. Однако это уже другая история, которая требует отдельного детального рассмотрения, осмысления и освещения.

\section{Литература}

1. Буканов В.В. Цветной камень. Энциклопедия. СПб. 2008. 415 с.

2. $\quad$ Глухов А.Б. Столица красивой тундры / Сост. А.Б. Глухов. Мурманск: РУСМА. 2017. 208 с.

3. Войтеховский Ю.Л., Жиров Д.В. Кольский тингуаит - уникальный поделочный камень // Север строительный. № 10 (19). 2006. С. 22-23.

4. Белянова Н.Л., Сенкевич Т.И., Туманова Л.Г. Музей цветного камня В.Н. Дава. // Тиетта. 2016. № 3 (37).

$$
\text { C. 32-34. }
$$

5. Бельков И.В. Амазонит // Драгоценные и цветные камни М.: Госгеолтехиздат. 1980. С. 110-117.

6. Волошин А.В. Майстерман С.А. Минералы Кольского полуострова. Мурманск. Книжное издательство. 1988. $128 \mathrm{c}$.

7. Дав В.Н. О вдовстве и «законе александрита» // Химия и жизнь. 1979. № 6. С. 86-87.

8. Дав В.Н. Аметист лихие думы отгоняет. Мурманск. Книжное издательство. 1981. 159 с.

9. Дав В.Н. Камни радости. Мурманск. Книжное издательство. 1988. 272 с.

10. Дав В.Н. Камни радости. Мурманск. Книжное издательство. 2017. 272 с.

11. Жиров Д.В. Ловозерский район / Жиров Д.В., Пожиленко В.И., Костина В.А. и др. // Серия «Памятники природы и достопримечательности Мурманской области». Санкт-Петербург. Изд-во Ника. 2008. 144 с.

12. Жиров Д.В., Лащук В.В. Облицовочный камень Мурманской области (справочно-методическое пособие). Апатиты. МУФ «Полиграф». 1998. 109 с.

13. Жиров Д.В., Лащук В.В. Декоративная гамма облицовочных и поделочных пород и минералов Кольского полуострова / Петрология и рудоносность регионов СНГ и Балтийского щита: Материалы X всерос. петрограф. совещания «Петрография XXI века». Апатиты. Изд. КНЦ РАН. 2005. Т. 3. С. 113-116.

14. Иванюк Г.Ю., Яковенчук В.Н., Пахомовский Я.А. Ковдор. Апатиты: Изд-во Минералы Лапландии. 2002. $326 \mathrm{c}$.

15. Киевленко Е.Я., Сенкевич Н.Н. Геология месторождений поделочных камней. М.: Недра. 1976. 280 c.

16. Теннер Д.Д. Декоративные камни Кольского полуострова и пути их комплексного изучения // Химия и технология переработки силикатного сырья. Л.: Наука. 1975. С. 88-103.

17. Ученые Кольского научного центра Академии Наук (1930-2010) / Под ред. акад. В.Т. Калинникова. Апатиты, изд. КНЦ РАН. 2010. 514 с.

18. Ферсман А.Е. Полезные ископаемые Кольского полуострова. М.-Л.: Изд. АН СССР. 1941. 345 с.

19. Шпанов И.А., Митрофанов Г.К. Облицовочные и поделочные камни СССР: атлас. М. Недра. 1970. 180 с. 